\title{
Is Natural Resource-Rich Russia Suffering from the Dutch Disease?
}

\author{
Assoc. Prof. Dr. Fikret Dülger (Çukurova University, Turkey) \\ Asst. Prof. Dr. Kenan Lopcu (Çukurova University, Turkey) \\ Ph.D. Candidate Almıla Burgaç (Çukurova University, Turkey) \\ Ph.D. Candidate Esra Ballı (Çukurova University, Turkey)
}

\begin{abstract}
"Dutch Disease" phenomenon is defined as the increase in the price of natural resources, such as oil and natural gas, which causes the appreciation of the real exchange rate and leads to the decline of manufacturing and ultimately to increases in service prices. Since the 1980s there has been a great body of "Dutch Disease" empirical literature, and as a natural resource-rich country Russia is a good case for the exploration of this phenomenon. The Russian economy experienced some difficulties after the collapse of the Soviet Union in the adaptation to a free market economy model. In the process of moving towards a free market economy, Russia failed to diversify its economic structure despite increases in natural resource revenues. In the last decades, while the share of natural resources in export revenues has significantly increased, the share of manufacturing output has decreased. According to the United Nations Development Program Russia report 2009, increases in energy income have resulted in the decline of other sectors of the Russian economy. Furthermore, the report claims that these indicators may trigger a recession in the Russian economy in the future. In fact, in recent years the Russian economy has exhibited some typical symptoms of "Dutch Disease" along with increases in oil prices accompanied by a reduction in the share of manufacturing output and an increase in service prices. Using Gregory Hansen cointegration method, this paper finds that Russia is in fact might be suffering from the "Dutch Disease" in the post Soviet Union-era.
\end{abstract}

JEL codes: F14, F31, C22

\section{Introduction}

Natural resource-poor economies such as Japan, Switzerland and Singapore outperform natural resource-rich countries such as Mexico, Venezuela, and Russia. Sachs and Warner (1995) showed that 97 developing countries with a high ratio of natural resource exports to GDP tend to have low growth rates for the period of 1971-1989. Krugman (1987) indicated that discovery of tradable natural resources, such as oil in a country leads to a real appreciation of its exchange rate and thus crowds out other tradable sectors of the country. A case in point in this regard is the Netherlands, where the competitiveness of Dutch manufacturing was clearly hurt by natural gas discoveries. The case is not limited to the Netherlands but supported by a number of other examples. What is interesting is that in conventional trade models this would not be regarded as a problem, and countries would simply be advised to specialize in what they have a comparative advantage in. In practice, nevertheless, the contraction of a country's manufacturing sector following natural resource discoveries causes a great deal of concern because of the fear that the lost manufacturing sectors will not come back when the natural resources run out Krugman (1987).

Corden (1984) noted that the concept of Dutch Disease is introduced for the first time in an article published in The Economist on November $26^{\text {th }} 1977$. Corden and Neary (1982) and Corden (1984) formed the first Dutch Disease model. The Core model consists of three sectors, namely the Booming Sector (B), the Lagging (Tradable) Sector $(\mathrm{L})$ and the Non-Tradable Sector $(\mathrm{N})$. The Booming and Lagging sectors produce tradable goods. Each sector uses labor and a factor specific to that sector to produce output and labor mobility between all three sectors equalizes the wage rate. According to the model, a boom in sector B increases the aggregate income in that sector for three possible reasons: (i) because of a technical progress which leads to a positive shift in the production function or (ii) a discovery of new resources or (iii) a rise in natural resource prices. Corden and Neary (1982) showed that natural resource boom affects the economy through both the spending effect and the resource movement effect. The resource movement effect can be explained as a result of the boom. When a boom happens in sector $\mathrm{B}$, the marginal product of labor increases in that sector and labor moves from sectors $\mathrm{L}$ and $\mathrm{N}$ to the Booming Sector, pushing wages up and shrinking the level of output in sectors $\mathrm{L}$ and $\mathrm{N}$ causing a direct de-industrialization. Meanwhile, in addition to the spending effect, decrease in output in sector $\mathrm{N}$ leads to an increase in prices in that sector further, and causes additional movement of labor out of $\mathrm{L}$ into $\mathrm{N}$, reinforcing the de-industrialization further, known as indirect de-industrialization. When factor owners or government spent the extra income earned in Sector $\mathrm{B}$, on the condition that the income elasticity for $\mathrm{N}$ is positive, the real exchange rate appreciates (The spending effect). Thus, the combination of these effects can cause a real exchange rate appreciation, a relative de-industrialization and a real wage growth. 
In the Russian case a boom happens when the price of oil increases. We consider the energy sector as the Booming Sector, the manufacturing sector as the Lagging Sector and the service sector as the non-tradable sector. This study investigates the real exchange rate appreciation and de-industrialization symptoms of Dutch Disease for energy resource-rich Russia using cointegration techniques with a structural change for the 1995:Q12011:Q2 period. The paper improves upon the existing empirical studies on the Russian Dutch Disease both in terms of employing a new dataset, as well as allowing a structural change that might have occurred over the sample period. Our findings indicate that Russia does indeed illustrate the symptoms of Dutch Disease. The rest of the paper is organized as follows. Section two presents the literature review. In section three, the data and the empirical methodology are discussed. Section four presents the empirical findings, and section five concludes.

\section{Literature Review}

There is a great deal of literature on "Dutch Disease", including a number of studies for the Russian case. Algieri (2011) investigated all the symptoms of the Dutch Disease for Russia for the 1993:11-2009:12 period using Vector Error Correction Model (VECM). The results showed that Russia exhibits the Dutch Disease symptoms, including relative de-industrialization.

Dobrynskaya and Turkisch (2010) investigated the trends in production, wages and employment in Russian manufacturing industry, and the effects of these trends on imports and exports for the period of 1997-2007. The results showed that although Russia had some symptoms of Dutch Disease, there was no sign of deindustrialization. They found that the employment decreased in the manufacturing sector and increased in the service sector, but at the same time production increased in the manufacturing sector. These results can be explained due to both the increase in productivity in the manufacturing sector and new market opportunities for Russia.

United Nations Development Program (UNDP) Russia report (2009) warned that, Russia may suffer from Dutch Disease in the near future. Specifically, the report indicated that the Russian state budget, investments and international trade were all heavily depended on world energy markets, making Russian economy vulnerable to global crises and affecting its long-term economic growth.

Ahrend, Rosa and Tompson (2007) analyzed the development of the Russian industry in comparison to the Ukrainian industry for the 1995-2004 period using revealed comparative advantage indexes. The results were ambiguous whether the Dutch Disease was apparent for Russia.

Ollus and Barisitz (2007) compared Russian industrial import growth with domestic industrial production growth for the period of 2002:01-2006:01. They found that Russia have an incipient to de-industrialization in some parts of the manufacturing sector. They indicated that Russian economy appears to have the symptoms of Dutch Disease. However, de-industrialization could have been driven not only by the Dutch Disease but other factors as well. Oomes and Kalcheva (2007) tested the Dutch Disease symptoms for Russia employing Johansen cointegration technique for the period of 1997:04-2005:12. The results were similar to that of Ollus and Barisitz (2007). That is although Russia appears to have the symptoms of the Dutch Disease, the de-industrialization could be the results of other dynamics.

Rautava (2004) investigated the effects of international oil prices, the real exchange rate and government revenues on Gross Domestic Product (GDP) for the Russian economy using Vector Autoregressions (VAR) and cointegration techniques for the period of 1995:Q1-2002:Q4. She found that changes in oil prices and the real exchange rate have significant effects on the long-run equilibrium condition and the short-run fluctuations of the Russian economy. The study concluded that although the underlying growth trend of the Russian economy has strengthened in recent years, there is no evidence that the role of oil prices has been reduced.

Overall the literature on Dutch Disease dealing with Russia has indicated that Russia suffers at least one of the symptoms of the Dutch Disease (The real exchange rate appreciation, increases in service prices and deindustrialization).

\section{Data and Empirical Methodology}

\subsection{Data}

The data set covers the period from 1995:Q1 to 2011:Q2. The dependent variables in our study are relative production of manufacturing to services and the CPI based reel effective exchange rate. The relative production of manufacturing to services is computed by dividing the production in manufacturing sector to the production in service sector. Manufacturing and service sector series are obtained from the Organization for Economic Cooperation and Development (OECD) and Rosstat. The real effective exchange rate is from the International Financial Statistics (IFS). We have used the price of oil and the relative productivity of manufacturing to services for Russia as independent variables. The price of oil extracted from the United States Energy Information Administration (EIA). Average labor productivity is used as a proxy for the productivity variable. In order to compute productivity in the manufacturing and service sectors, the total output in each sector is divided by the 
employment level in that sector. The relative productivity is defined as productivity in the manufacturing sector divided by productivity in the service sector. The output and employment series are obtained from the OECD, the International Labor Organization (ILO), the Russian-European Centre for Economic Policy (RECEP) and the Rosstat. All the sectoral output and employment series for Russia are seasonally adjusted using X-12, before the average productivity for each sub-sector is calculated. All variables are converted into natural logarithm. An increase in the real effective exchange rate corresponds to appreciation of the Russian Ruble.

To analyze the symptoms of Dutch Disease for Russia, following Algieri (2011), we use two main regression models with the relative production of manufacturing to services and the real effective exchange rate as dependent variables.

$$
\begin{aligned}
& \text { Model I }: \text { yman } / \text { yserv }_{t}=\text { cons }+\beta_{1} \operatorname{prod}_{t}+\beta_{2} \text { poil }_{t}+\varepsilon_{t} \\
& \text { Model II }: \text { reer }_{t}=\text { cons }+\beta_{1} \operatorname{prod}_{t}+\beta_{2} \text { poil }_{t}+\varepsilon_{t}
\end{aligned}
$$

Where yman/yserv stands for the relative production in manufacturing sector to service sector, prod is the relative productivity of manufacturing to services, poil denotes the price of oil and reer shows the reel effective exchange rate. Model I and Model II represent de-industrialization and the real exchange rate appreciation symptoms of Dutch Disease respectively.

\subsection{Econometric Methodology}

We start by investigating the order of integration of the variables using the $A D F$ (Dickey and Fuller, 1981) and KPSS (Kwiatkowski-Phillips-Schmidt-Shin, 1992) tests. We test the long run relationship between variables using Gregory-Hansen (1996) cointegration test which allows for a structural break. Gregory-Hansen (1996) provides a residual based test with one structural change in the cointegration relationship at an unknown time during the sample period. The structural break is determined endogenously. The null hypothesis is no cointegration against the alternative hypothesis of cointegration in the presence of a structural break.

The dummy variable that indicates the structural change is defined as follows (Gregory Hansen, 1996, p.102103):

$$
\varphi_{t \tau}= \begin{cases}O \text { if } & \mathrm{t} \leq[\mathrm{n} \tau] \\ 1 \text { if } & \mathrm{t}>[\mathrm{n} \tau]\end{cases}
$$

Where the unknown parameter $\tau \in(0,1)$ denotes the timing of the structural change point and [ ] denotes the integer part. Gregory-Hansen (1996) developed three models for testing cointegration under the structural break.

(GH-1): Level Shift

$$
\mathrm{y}_{1 \mathrm{t}}=\mu_{1}+\mu_{2} \varphi_{\mathrm{t} \tau}+\alpha^{\mathrm{T}} \mathrm{y}_{2 \mathrm{t}}+\varepsilon_{\mathrm{t}}, \quad \quad t=1, \ldots \ldots n .
$$

A level shift model allows only a change in the intercept. $\mu_{1}$ presents the intercept before the shift and $\mu_{2}$ shows the change in the intercept at the time of the shift.

(GH-2): Level Shift with trend

$$
y_{1 t}=\mu_{1}+\mu_{2} \varphi_{t \tau}+\beta t+\alpha^{T} y_{2 t}+\varepsilon_{t}, \quad t=1, \ldots \ldots n .
$$

The second model includes a time trend and permits a break in the intercept as the previous model (Level shift with trend).

(GH-3): Regime Shift

$$
\mathrm{y}_{1 \mathrm{t}}=\mu_{1}+\mu_{2} \varphi_{\mathrm{t} \tau}+\alpha_{1}{ }^{\mathrm{T}} \mathrm{y}_{2 \mathrm{t}}+\alpha_{2}{ }^{\mathrm{T}} \mathrm{y}_{2} \varphi_{\mathrm{t} \tau}+\varepsilon_{\mathrm{t}}, \quad \quad t=1, \ldots \ldots . n .
$$

In the third model the structural change allows the slope vector to shift as well. This model is called the regime shift model. $\mu_{1}$ and $\mu_{2}$ are as in the level shift model, $\alpha_{1}{ }^{\mathrm{T}}$ denotes the cointegration slope coefficients before the regime change and $\alpha_{2}{ }^{\mathrm{T}}$ denotes the change in the slope coefficients after the regime change.

In these three models, dummy variable, $\varphi_{t t}$, takes value $(0,1)$. Non-stationarity of the residuals under the null hypothesis is tested by the modified Phillips-Perron $(P P)$ unit root tests $\left(Z_{t}\right.$ and $\left.Z_{\alpha}\right)$ and the $A D F$ test statistic, using the smallest value of these statistics across all possible break points.

$$
\begin{aligned}
& Z_{\alpha}^{*}=\min _{\tau \in T} Z_{\alpha}(\tau), \\
& Z_{t}^{*}=\min _{\tau \in T} Z_{t}(\tau), \\
& A D F^{*}=\min _{\tau \in T} A D F(\tau) .
\end{aligned}
$$




\section{Empirical Results}

Table 1 shows the $A D F$ and KPSS unit root tests. The $A D F$ tests reveal that none of the variables are stationary at $1 \%$ significance level while the KPSS tests indicate that all the variables are non-stationary at $10 \%$ significance level. On the other hand, all the variables are stationary in the first differences according to all $A D F$ and KPSS tests. Hence, we conclude that all the variables are integrated order of one, I (1), at levels.

We test the long run relationship between variables using Gregory Hansen test (1996). Table 2 presents the results for Model I. The results provide some evidence of cointegration between the relative production of manufacturing to services, the relative productivity and the price of oil for both GH-1 and GH-2 models, but none for GH-3 model. For GH-1 the null hypothesis is rejected at $10 \%$ significance level by the $A D F, Z_{\alpha}$ and at $5 \%$ significance level by $Z_{t}$ tests, while for GH-2 the null hypothesis is not rejected by the $A D F$ and $Z_{\alpha}$ tests, but we find evidence of cointegration according to $Z_{t}$ test. Endogenously determined break dates with significant cointegration relationships coincide with the global economic crises of 2008 for both GH-1 and GH-2 models.

The results for Model II are reported in Table 3 (reer=prod poil). According to the results, we find cointegration at 5\% significance level for GH-1 and GH-2 using ADF test, and at $10 \%$ significance level for GH2 using $Z_{t}$ test. Remaining tests for $\mathrm{GH}-1$ and $\mathrm{GH}-2$ and all the tests for GH-3 provide no evidence of cointegration between reer, prod and poil. It should be noted that the break points for all models follow immediately the Asian and Russian economic crises of 1997-1998.

\begin{tabular}{|c|c|c|c|c|c|c|c|c|}
\hline \multirow[b]{3}{*}{ Variables } & \multicolumn{6}{|c|}{ ADF } & & \\
\hline & \multicolumn{2}{|c|}{ Model A } & \multicolumn{2}{|c|}{ Model B } & \multicolumn{2}{|c|}{ Model C } & \multicolumn{2}{|c|}{ KPSS } \\
\hline & $k$ & $t_{(\gamma)}$ & $k$ & $t_{(\gamma)}$ & $k$ & $t(\gamma)$ & $\eta_{\mu}$ & $\eta_{\tau}$ \\
\hline yman/yserv & 0 & $-3.71^{* *}$ & 0 & -0.50 & 0 & 0.55 & $1.26^{* * *}$ & $0.15^{* *}$ \\
\hline reer & 1 & -2.59 & 1 & -1.84 & 1 & 0.79 & $0.90^{* * *}$ & $0.18^{* * *}$ \\
\hline prod & 1 & -1.42 & 1 & -1.45 & 1 & -0.81 & $0.57^{* *}$ & $0.22^{* * *}$ \\
\hline poil & 3 & $-3.24^{*}$ & 2 & -0.57 & 2 & 1.38 & $1.30^{* * *}$ & $0.12^{*}$ \\
\hline$d(y m a n / y s e r v)$ & 0 & $-7.98^{* * *}$ & 1 & $-8.05^{* * *}$ & 1 & $-7.97^{* * * *}$ & 0.18 & 0.07 \\
\hline dreer & 0 & $-5.67^{* * *}$ & 0 & $-5.72^{* * *}$ & 0 & $-5.66^{* * *}$ & 0.06 & 0.06 \\
\hline dprod & 0 & $-10.77^{* * *}$ & 0 & $-10.83^{* * *}$ & 0 & $-10.91^{* * *}$ & 0.26 & 0.05 \\
\hline dpoil & 1 & $-6.27^{* * *}$ & 1 & $-6.29^{* * *}$ & 1 & $-6.05^{* * *}$ & 0.21 & 0.10 \\
\hline \multirow{3}{*}{$\begin{array}{l}\text { Critical } \\
\text { Value }\end{array}$} & $1 \%$ & -4.06 & & -3.50 & & -2.59 & 0.74 & 0.21 \\
\hline & $5 \%$ & -3.46 & & -2.89 & & -1.95 & 0.46 & 0.14 \\
\hline & $10 \%$ & -3.15 & & -2.58 & & -1.61 & 0.34 & 0.11 \\
\hline
\end{tabular}

Table 1. ADF and KPSS Unit Root Tests

\begin{tabular}{|c|c|c|c|c|c|c|c|}
\hline & $k$ & $A D F$ & $\begin{array}{l}\text { Break } \\
\text { Date }\end{array}$ & $Z_{t}$ & $\begin{array}{l}\text { Break } \\
\text { Date }\end{array}$ & $Z_{\alpha}$ & $\begin{array}{l}\text { Break } \\
\text { Date }\end{array}$ \\
\hline GH-1 & 0 & $\begin{array}{l}-4.80^{*} \\
(0.81)\end{array}$ & 2008:Q1 & $\begin{array}{l}-5.84^{* * *} \\
(0.83)\end{array}$ & 2008:Q2 & $\begin{array}{c}-43.84^{*} \\
(0.83)\end{array}$ & 2008:Q2 \\
\hline GH-2 & 0 & $\begin{array}{l}-4.43 \\
(0.16)\end{array}$ & 1997:Q3 & $\begin{array}{l}-5.21^{*} \\
(0.83)\end{array}$ & 2008:Q2 & $\begin{array}{c}-36.72 \\
(0.83)\end{array}$ & 2008:Q2 \\
\hline GH-3 & 7 & $\begin{array}{l}-4.93 \\
(0.62)\end{array}$ & 2005:Q1 & $\begin{array}{l}-4.87 \\
(0.83)\end{array}$ & 2008:Q2 & $\begin{array}{c}-33.40 \\
(0.83)\end{array}$ & 2008:Q2 \\
\hline
\end{tabular}

***: significant at 10 and $5 \%$ levels respectively; $A D F$ and $Z_{t} \% 5$ and \%10 critical values: GH-1:- 4.92,-4.69; GH-2: -5.29,-5.03; GH-3: $-5.50,-5.23 ; Z_{\alpha}, \% 5$ and $\% 10$ critical values : GH-1: $-46.98,-42.49 ; \mathrm{GH}-2:-53.92,-48.94 ;$ GH-3: $-58.33,-52.85$; The structural break is given in the parentheses. $k$ denotes number of lags and determined by the $t$ ratio.

Table 2. Test for Cointegration with Structural Break (yman/yserv=prod poil)

\begin{tabular}{|c|c|c|c|c|c|c|c|}
\hline & $k$ & $A D F$ & $\begin{array}{c}\text { Break } \\
\text { Date }\end{array}$ & $Z_{t}$ & $\begin{array}{c}\text { Break } \\
\text { Date }\end{array}$ & $Z_{\alpha}$ & $\begin{array}{c}\text { Break } \\
\text { Date }\end{array}$ \\
\hline GH-1 & 1 & $\begin{array}{c}-5.66^{* * *} \\
(0.26)\end{array}$ & 1999:Q2 & $\begin{array}{c}-4.64 \\
(0.24)\end{array}$ & 1999:Q1 & $\begin{array}{c}-27.27 \\
(0.24)\end{array}$ & 1999:Q1 \\
\hline GH-2 & 1 & $\begin{array}{c}-5.65^{* *} \\
(0.26)\end{array}$ & 1999:Q2 & $\begin{array}{c}-5.17^{*} \\
(0.21)\end{array}$ & 1998:Q3 & $\begin{array}{c}-30.06 \\
(0.24)\end{array}$ & 1999:Q1 \\
\hline GH-3 & 0 & $\begin{array}{r}-4.18 \\
(0.21)\end{array}$ & 1998:Q3 & $\begin{array}{r}-4.79 \\
(0.24)\end{array}$ & 1999:Q1 & $\begin{array}{c}-34.32 \\
(0.24)\end{array}$ & 1999:Q1 \\
\hline
\end{tabular}

Table 3. Test for Cointegration with Structural Break (reer=prod poil) 
The estimated results for cointegration relationship for Model I are reported in Table 4. All the coefficients for both GH-1 and GH-2 models are significant with the exception of the constant term for the GH-2 model. The coefficients on prod and poil have a priori expected signs for both models. The coefficients on the dummy variable for both models are negative and the magnitudes indicate a sizeable de-industrialization after the break point. According to the results, 1 percentage point increase in the price of oil leads to 0.14 and 0.09 percentages decrease in the relative production of manufacturing to services in GH-1 and GH-2 models respectively. These results are supportive of the Dutch Disease for Russia. The relative productivity coefficients, on the other hand, are positive for both models. Specifically, a percentage point increase in the relative productivity will increase the relative production of manufacturing to services by 1.33 and 1.23 percentages in $\mathrm{GH}-1$ and GH-2 models respectively. It is also worth noting that the impact of prod and poil tend to neutralize each other but the impact of prod overweighs that of poil in GH-2 model by a large margin. The coefficient of the trend in GH-2 model is negative, indicating a slow tendency of Russia to de-industrialize over time.

Given the evidence of cointegration for Model II in Table 3, we estimate the model for the real exchange rate with a structural change. The estimated results are reported in Table 5. The results show that prod is significant neither for GH-1 nor for GH-2 models while poil is positive and significant in both models, a symptom of Dutch Disease. Specifically, a one percentage point increase in poil appreciates the reer by 0.37 and 0.21 in GH-1 and GH-2 models respectively. Additionally, positive and significant trend in GH-2 model indicates the tendency of the Ruble to appreciate. The coefficients for the dummy variable in both models are negative, indicating the depreciation of the Ruble at the break point.

\begin{tabular}{|c|c|}
\hline GH-1 & $\begin{array}{c}\text { yman/yserv }=0.088-0.351 \text { dummy }+1.333 \text { prod }-0.139 \text { poil } \\
(2.33) \quad(-17.21)\end{array}$ \\
\hline GH-2 & 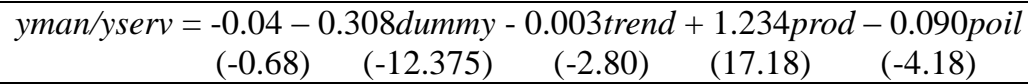 \\
\hline
\end{tabular}

$t$ values are in parenthesis

Table 4. The Estimated Results for Gregory Hansen Cointegration Test (yman/yserv=prod poil)

\begin{tabular}{|c|c|}
\hline GH-1 & $\begin{array}{ccc}\text { reer }=3.96-0.32 \text { dummy }-0.02 \text { prod }+0.37 \text { poil } \\
(37.84) & (-6.05) & (-0.09)\end{array}$ \\
\hline GH-2 & $\begin{array}{c}\text { reer }=4.35-0.40 \text { dummy }+0.007 \text { trend }+0.03 \text { prod }+0.21 \text { poil } \\
(28.12) \quad(-7.27)\end{array}$ \\
\hline
\end{tabular}

Table 5. The Estimated Results for Gregory Hansen Cointegration Test (reer=prod poil)

\section{Conclusion}

Given the span of the dataset and econometric techniques employed, the results show that Russia appears to have the symptoms of Dutch Disease. These results are consistent with the literature cited earlier and the UNDP Russia Report (2009). If the oil begins to run out or price of oil decreases, manufacturing industries may not recover quickly to replace the oil sector. Thus, Russia may lose its competitive position in manufacturing and as a result, a recession may be triggered in the near future. However, the de-industrialization process could have been driven by other factors as emphasized by Dobrynskaya \& Turkisch (2010) and Oomes \& Kalcheva (2007). These authors recognize that the de-industrialization and the real appreciation of the Ruble are both symptoms of the Dutch Disease. However, increases in productivity, expanding domestic market and the occurrence of the new market opportunities after the collapse of the Soviet Union could also be the causes of these indicators. Future research can scrutinize potential causes for the presence of these "symptoms" further.

\section{References}

- Algieri, B. (2011), “The Dutch Disease: evidences from Russia”, Econ Change Restruct, 44, pp 243-277.

- Ahrend, R., D. Rosa. and W. Tompson (2007), "Russian Manufacturing and the Threat of Dutch Disease - A Comparison of Competitiveness Developments in Russian and Ukrainian Industry”, OECD Economics Department Working Paper, 540.

- Corden, W. M. (1984), "Booming Sector and Dutch Disease Economics: Survey and Consolidation”, Oxford Economic Papers, New Series, 36, (3), pp. 359-380. 
- Corden, W. M., and J. P. Neary (1982), "Booming Sector and De-Industrialization in a Small Open Economy” The Economic Journal, 92 (368), 1982, 825-848.

- Dickey, D A. and Fuller, W. A. (1981). Likelihood Ratio Statics for Autoregressive Time Series with a Unit Root. Econometrica. 49. 1057-1072.

- Dobrynskaya, V. and E. Turkisch (2010), "Economic Diversification and Dutch Disease in Russia", PostCommunist Economies, 22 (3), pp. 283-302.

- Gregory, A. W. and B.E. Hansen. (1996), "Tests for the Cointegration in Models with Regime and Trend Shifts", Oxford Bulletin of Economics and Statistics, 58 (3), pp.555-560.

- Krugman, P. (1987), "The Narrow Moving Band, the Dutch Disease and the Competitive Consequences of Mrs. Thatcher on Trade in the Presence of Dynamic Scale Economies", Journal of Development Economics, 27, pp. 41-55.

- $\quad$ Kwiatkowski, D., Philiphs, P. C.B., Schmidt, P. and Shin, Y. (1992). Testing the Null Hypothesis of Stationarity Against the Alternative of a Unit Root, How sure are we that Economic Time Series have a Unit Root. Journal of Econometrics, 54, 159-178.

- Ollus and Barisitz (2007) "The Russian Nonfuel Sector: Signs of the Dutch Disease? Evidence from EU-25 Import Competition", Bofit Online, 2.

- Oomes, N. and K. Kalcheva (2007), “Diagnosing Dutch Disease: Does Russia Have the Symptoms?”, IMF Working Paper, 102.

- Rautava J (2004) The role of oil prices and the real exchange rate in Russia's Economy-a Cointegration Approach.”, Journal of Comparative Economics, 32(2), pp. 315-327.

- Sachs J, and Warner,A (1995), "Natural Resource Abundance and Economic Growth", National Bureau of Economic Research, 5398.

- UNDP Russia Report, 2009, "Energy Sector and Sustainable Development”. 